\title{
UNSUR PEMBELAJARAN EDUTAINMENT DALAM QUANTUM LEARNING
}

\author{
Setyoadi Purwanto,S.Pd. M.Pd.I. \\ STPI Bina Insan Mulia - Yogyakarta \\ adikitana06@gmail.com
}

\begin{abstract}
Early childhood learning uses the principle of playing while learning so that it must be arranged so that it is fun, uplifting, and democratic. Quantum Learning is a learning method that is loaded with edutainment concepts. Based on the studies conducted, the following conclusions are obtained: (1) Quantum learning and edutainment both emphasize the urgency of a pleasant and easy atmosphere; (2) Equally starting from the world of non-education; (3) Both give primary attention to an exciting learning process, which involves physical-sensory, emotional, and suggestive beliefs; (4) Quantum learning and edutaintment are able to foster student confidence; (5) Quantum learning builds student learning skills through a variety of cutting-edge discoveries, and edutainment continually seeks to facilitate optimal learning processes; (6) Quantum learning and edutaintment simultaneously build effective communication to students.
\end{abstract}

Keywords: learning, quantum learning, edutaintmen

\begin{abstract}
ABSTRAK
Pembelajaran anak usia dini menggunakan prinsip bermain sambil belajar sehingga harus disusun sehingga menyenangkan, menggembirakan, dan demokratis. Quantum Learning adalah metode pembelajaran yang sarat dengan konsep edutainment. Berdasarkan kajian yang telah dilakukan maka diperoleh kesimpulan sebagai berikut: (1) Quantum learning dan edutainment sama-sama menekankan urgensi suasana menyenangkan dan memudahkan; (2) Sama-sama bermula dari dunia non pendidikan; (3) Keduanya memberi perhatian utama pada proses belajar yang menggairahkan, yang melibatkan fisik-inderawi, emosi, dan keyakinan-sugetif; (4) Quantum learning dan edutaintment mampu menumbuhkan rasa percaya diri siswa; (5) Quantum learning membangun keterampilan belajar siswa melalui berbagai penemuan mutakhir, dan edutainment terus-meneus berupaya memfasilitasi proses pembelajaran optimal; (6) Quantum learning dan edutaintment secara bersamaan membangun komunikasi efektif kepada peserta didik.
\end{abstract}

Kata kunci: pembelajaran, quantum learning, edutaintmen 


\section{A. PENDAHULUAN}

Pembelajaran anak usia dini menggunakan prinsip, bermain sambil belajar. Prinsip ini sejalan dengan fitrah anak sebagai makhluk bermain, dan dunia mereka adalah dunia bemain. Pembelajaran untuk anak usia dini harus disusun sehingga menyenangkan, menggembirakan, dan demokratis agar menarik anak untuk terlibat dalam setiap kegiatan pembelajaran. Anak aktif berinteraksi dengan berbagai benda dan orang di lingkungannya, baik secara fisik maupun mental (Suyanto, 2005: 127).

Belajar melalui bermain bagi anakanak akan terasa menggairahkan dan menggembirakan. Kegembiraan lebih penting dari obat apa pun. Sekolah haruslah menjadi ajang kegiatan yang paling menyenangkan dan menggairahkan, demikian menurut penulis buku The Accelerated Learning Handbook, Dave Meier sebagaimana dikutib Hernowo (Hernowo, 2004: 15-17).

Quantum learning adalah teori belajar yang menekankan belajar sebagai suatu proses yang menyenangkan dan bermakna. Hal ini sangat selaras dengan konsep edutainment yang kini banyak dikembangkan dalam kegiatan pembelajaran. Konsep edutainment adalah sebuah konsep yang memadukan dunia pendidikan (education) dengan dunia hiburan (entertainment). Dua hal yang dulu sering dianggap berada pada posisi kontradiktif dan berseberangan.

Makalah singkat ini sengaja tidak mengulang pembahasan dasar tentang edutainment akan tetapi langsung terfokus pada teori Quantum Learning. Secara khusus makalah ini akan mencermati berbagai unsur edutainment dalam quantum learning sesuai judul yang diangkatnya.

\section{B. PEMBAHASAN}

1. Quantum Learning

\section{a. Sejarah Quantum Learning}

Perintis, pencetus, dan pengembang utama pembelajaran kuantum adalah Bobbi DePorter. Prinsip pembelajaran quantum pertama kali diterapkan dalam sekolah bisnis Burklyn yang didirikannya pada akhir tahun 1970. Burklyn adalah sekolah bisnis yang mengajarkan materi konvensional dengan cara-cara yang tidak biasa. Inti metodenya menggabungkan upaya memperkuat tubuh, memperkaya jiwa, sekaligus mendidik pikiran.

Selanjutnya prinsip-prinsip dan metode-metode Quantum Learning semakin menemukan bentuknya ketika ia bersama teamnya mengembangkan SuperCamp pada awal 1980-an (DePorter, 1999: 2). SuperCamp, sebuah lembaga pembelajaran yang terletak Kirkwood Meadows, Negara Bagian California, Amerika Serikat, didirikan atau dilahirkan oleh Learning Forum, sebuah perusahahan yang memusatkan perhatian pada hal-ihwal pembelajaran guna pengembanga potensi diri manusia. Dengan dibantu oleh teman-temannya, terutama Eric Jansen, Greg Simmons, Mike Hernacki, Mark Reardon, dan Sarah Singer-Nourie, DePorter secara terprogram dan terencana mengujicobakan gagasan-gagasan pembelajaran kuantum kepada para remaja, hingga saat ini.

Saat ini metode pembelajaran kuantum merambah berbagai tempat dan bidang kegiatan manusia, mulai lingkungan pengasuhan di rumah, lingkungan bisnis, lingkungan 
perusahaan, lebih-lebih di lingkungan kelas (sekolah).

\section{b. Definisi dan Prinsip Quantum Learning}

Istilah quantum pada awalnya digunakan dalam bidang fisika, yakni fisika quantum. Namun demikian, falsafah dan metodologi pembelajaran kuantum tidaklah diturunkan atau ditransformasikan secara langsung dari fisika kuantum yang sekarang sedang berkembang pesat. Tidak pula ditransformasikan dari prinsip-prinsip dan pandanganpandangan utama fisika kuantum yang dikemukakan oleh Albert Einstein, seorang tokoh terdepan fisika kuantum. Jika ditelaah atau dibandingkan secara cermat, istilah kuantum [quantum] yang melekat pada istilah pembelajaran [learning] ternyata tampak berbeda dengan konsep kuantum dalam fisika kuantum.

Sedikit kemiripannya

terutama terlihat dalam konsep kuantum. Dalam fisika kuantum, istilah kuantum memang diberi konsep perubahan energi menjadi cahaya selain diyakini adanya ketakteraturan dan indeterminisme alam semesta. DePorter selanjutnya mendifinisikan Quantum Learning sebagai "interaksi-interaksi yang mengubah energi menjadi cahaya." Mereka mengamsalkan kekuatan energi sebagai bagian penting dari tiap interaksi manusia. Dengan mengutip rumus klasik $\mathrm{E}=\mathrm{mc} 2$, mereka alihkan ihwal energi itu ke dalam analogi tubuh manusia yang "secara fisik adalah materi". Sebagai pelajar, tujuan kita adalah meraih sebanyak mungkin cahaya; interaksi, hubungan,
menghasilkan $\begin{array}{r}\text { agar } \\ \text { energi }\end{array}$

(DePorter: 1999, 16).

Quantum learning ialah kiat, petunjuk, strategi, dan seluruh proses belajar yang dapat mempertajam pemahaman dan daya ingat, serta membuat belajar sebagai suatu untuk melakukan eksperimen yang disebutnya sebagai "Suggestology" atau "Suggestopedia".Istilah lain dari suggestology adalah accelerated learning.

Quantum learning bisa jadi merupakan teori pembelajaran yang paling handal pada saat ini. Penggabungan dari beberapa model pengajaran dan pembelajaran seperti accelerated learning, multiple inteligencies, brain research, neuro-linguistic programming, learning modalities, experiental learning dan kooperative learning terpadu dalam suatu pengetahuan tunggal yang menghasilkan suatu pembelajaran yang sangat bertenaga. Seperti orkestra dalam sebuah simfoni, berbagai elemen ini diorkestra secara hati-hati untuk menciptakan suatu pengalaman belajar yang lebih lengkap dan menyenangkan. Jadi dapat dinyatakan bahwa quantum learning merupakan kiat, petunjuk, strategi, dan seluruh proses belajar yang dapat mempertajam pemahaman dan daya ingat, serta membuat belajar sebagai suatu proses yang menyenangkan dan bermanfaat. Beberapa teknik yang dikemukakan merupakan teknik meningkatkan kemampuan diri yang sudah populer dan umum digunakan. Namun, Bobbi DePorter mengembangkan teknik-teknik yang sasaran akhirnya ditujukan untuk membantu para siswa menjadi responsif dan 
bergairah dalam menghadapi tantangan dan perubahan realitas.

\section{c. Manfaat Utama Quantum Learning}

Perkembangan Quantum

Learning memang tidak terlepas dari Supercamp. Kurikulum SuperCamp merupakan kombinasi harmonis dari tiga unsur: ketrampilan akademis, prestasi fisik dan ketrampilan hidup (life skill). Ketiga unsur kurikulum tersebut diarahkan untuk mewujudkan 3 hal: penumbuhan rasa percaya diri, ketrampilan belajar, dan ketrampilan berkomunikasi dalam lingkungan yang menyenangkan (Deporter, 1999: 4-9). Dalam Quantum Learning, tiga aspek yang menjadi sasaran tujuan SuperCamp tersebut selanjutnya dikembangkan menjadi berbagai bidang ketrampilan seperti: bersikap positif, motivasi belajar, menemukan cara belajar yang tepat, menciptakan lingkungan belajar sempurna, membaca cepat, membuat catatan efektif, berpikir kreatif, mengembangkan kemampuan super memori dan lainlain.

\section{Karakteristik Edutainment}

Edutainment bisa didefinisikan sebagai proses pembelajaran yang didesain dengan memadukan antara muatan pendidikan dan hiburan secara harmonis sehingga aktivitas pembelajaran berlangsung menyenangkan (Hamruni, 2009: 50). Konsep edutainment pertama kali digunakan di dunia hiburan, oleh The Walt Disney Company. Saat ini edutainment digunakan dan dikembangkan oleh produsen mainan anak, pengelola tempat hiburan, media, dan lembaga pendidikan formal maupun non formal. Makalah ini akan membatasi dan memfokuskan istilah edutainment dalam dunia pendidikan.

Ada 4 (empat) prinsip yang menjadi karakteristik dari konsep edutainment dalam pembelajaran antara lain: (Hamruni, 2009: 42-45).

a. Menjembatani proses belajar dan proses mengajar

b. Pembelajaran edutainment berlangsung dalam suasana kondusif dan menyenangkan yang didasari 3 asumsi:

1) Perasaan gembira akan mempercepat pembelajaran, sedangkan perasaan negative, seperti terancam, takut, sedih, merasa tidak mampu akan memperlambat belajar bahkan menghentikannya.

2) Jika seseorang menggunakan potensi nalar dan emosinya secara jitu, maka akan menghasilkan lompatan prestasi belajar.

3) Dengan menggunakan metode pembelajaran yang tepat yang mengakomodir gaya dan keunikan belajar siswa, maka belajar akan dapat dioptimalkan.

c. Menempatkan anak sebagai pusat sekaligus subyek pendidikan. Pembelajaran diawali dengan menggali dan memahami kebutuhan anak.

d. Pembelajaran yang lebih humanis.

\section{Mencermati Unsur Edutainment dalam Quantum Learning}

Edutainment dan quantum learning seolah memiliki akar dan jiwa yang sama. Hal ini terlihat jika kita mencoba mencermati dan menghubungkan berbagai unsur edutainment yang tampak dari 4 karakteristiknya dengan berbagai aktivitas 
yang menjadi cirikhas pembelajaran quantum learning. Quantum Learning yaitu orkestrasi bermacam-macam interaksi yang ada di dalam dan di sekitar situasi belajar. Interaksi ini mencakup unsur-unsur untuk belajar efektif yang mempengaruhi kesuksesan siswa, mengubah kemampuan dan bakat alamiah siswa menjadi cahaya yang akan bermanfaat bagi mereka sendiri dan bagi orang lain. Pada bagian akhir tulisan ini, penulis mencoba menghubungkan berbagai interaksi quantum tersebut dengan 4 karakteristik edutainment.

\section{a. Menumbuhkan Rasa Percaya Diri}

Berbagai interaksi quantum yang termasuk dalam kategori ini antara lain:

1) Membangun kekuatan pikiran melalui pendekatan sugesti (DePorter, 1999: 21-22). Dalam hal ini sangat tampak pengaruh NLP dalam pengembangan quantum learning. Quantum learning mencakup aspek-aspek penting dalam program neurolinguistik (NLP), yaitu suatu penelitian tentang bagaimana otak mengatur informasi. Program ini meneliti hubungan antara bahasa dan perilaku dan dapat digunakan untuk menciptakan jalinan pengertian siswa dan guru. Salah satu sumbangan NLP dalam Quantum Learning adalah sugesti positif siswa dalam belajar. Bayangkan, apa yang terjadi jika para siswa merasa sangat yakin, bahwa mereka tak mungkin gagal? NLP membedakan orang yang memiliki peluang sukses dengan orang yang sangat yakin sukses, orang yang kompeten dan orang yang sangat unggul di bidang yang sama. NLP adalah ilmu keunggulan seni perubahan (Agnes, 2010: 26).

2) Menumbuhkan motivasi belajar mandiri melalui AMBAK (Apa manfaatnya bagiku) dan memupuk sikap juara. Segala sesuatu yang ingin Anda kerjakan harus menjanjikan manfaat bagi Anda, atau Anda tidak akan termotivasi untuk melakukannya (DePorter, 1999: 46). Dan berpikir seperti seorang juara membuat Anda menjadi juara. Itulah pentingnya mengetahui bagaimana memupuk sikap juara (DePorter, 1999: 90).

3) Mengelola sikap tubuh dan emosi positif yang akan mempercepat pembelajaran (Hamruni, 2009: 43).

Kekuatan pikiran, motivasi belajar, sikap tubuh dan emosi positif sebagai interaksi quantum ini selaras dengan 3 karakteristik edutainment yaitu: (1) upaya mewujudkan pembelajaran yang lebih humanis, menjembatani jurang pemisah antara proses belajar dan proses mengajar, dan (3) menjadikan siswa sebagai pusat sekaligus subyek pendidikan.

\section{b. Mengelola dan Meningkatkan Ketrampilan Belajar}

Interaksi quantum yang termasuk dalam kategori ketrampilan belajar ini antara lain:

\section{1) Learn how to learn.}

Hal yang paling berharga dalam belajar adalah bagaimana cara belajar (DePorter, 1999: 2). Quantum learning dan edutainment adalah dua konsep yang bertemu dalam hal 
penekanan proses pembelajaran yang menyenangkan, bukan semata hasil yang diharapkan. Oleh karenanya selain materi, cara mentransfer materi menjadi sesuatu ang jauh lebih penting lagi.

\section{2) Global learning}

Global learning merupakan cara efektif dan alamiah bagi seseoang untuk mempelajari sesuatu (Hamruni, 2009: 58). Semua aktivitas fisik-inderawi, emosi, dan sugesti saling menguatkan dalam pembelajaran menyeluruh ini. Sama seperti quantum learning, edutainment pun menggunakan prinsip fariasi dalam pembelajaran, yang melibatkan total aktivitas siswa dan guru dalam pembelajaran.

3) Mempelajari

Teknik

Mendengar Aktif dan

Mencatat Efektif.

Mendengar aktif diawali dengan menumbuhkan minat. Teknik sederhana yang bisa digunakan misalnya dengan membuata pertanyaan, "Apa yang dapat saya pelajari dari pembicara? Apa hubungannya dengan maalah ini? Pentingkah itu? Apakah itu harus saya ingat?" (DePorter, 1999: 166). Teknik mencatat efektif menggunakan symbol visual pertama dikenalkan oleh Tony Buzan berupa mind maping (peta pikiran). Selain Mindmap, quantum learning mengenalkan beberapa teknik lain, seperti TS (tulis-susun) yang dikenalkan oleh Mark Reardon (DePorter, 1999: 162). Semua ketrampilan ini sangat menantang dan mengasyikkan serta menghibur (entertain).

4) Mempelajari Teknik Membaca Cepat dan Menulis Mudah.

Membaca dan menulis adalah aktivitas mendasar dalam setiap proses pembelajaran. Paradigma pembelajaran lama hanya menekankan apa yang harus dibaca dan apa yang wajib ditulis. Bagaimana seharusnya kita membaca dan bagaimana pula teknik menulis jarang menjadi perhatian. Quantum learning dan pembelajaran edutainment menjadikan dua aktivitas yang 'menjemukan' ini menjadi kegiatan menarik dan menantang. Beberapa kiat membaca menurut quantum learning antara lain: (1) mempersiapkan diri; (2) meminimalkan gangguan; (3) duduk dengan sikap tegak; (4) tenangkan pikiran; (5) gunakan jari atau alat penunjuk; (6) lihatlah sekilas bacaan sebelum membacanya (DePorter, 1999: 252-259).

Menulis adalah aktivitas seluruh otak ang melibakan belahan kanan (emosional) dan belahan kiri (logika). Teknik brainstorming, dan clustering (pengelompokan aktivitas) ini menjadikan menulis produktif tanpa stress.

5) Upayakan Keajaiban Memori Eksperimen yang dilakukan terhadap otak manusia manyimpulkan bahwa Anda dapat mengingat setiap informasi apapun yang pernah Anda ketahui (DePorter, 1999: 206). Pikiran menyimpan segala 
sesuatu dan mengingat apa yang diperlukan dan berarti saja. Quantum learning mayakini, untuk menguatkan kualitas memori dan daya ingat, informasi harus diolah menjadi pengalaman yang memiliki kualitas:

asosiasi inderawi terutama visual:

(2) konteks emosional yang menjadi anchor, (3) sesuatu yang menonjol dan beda; (4) asosiasi yang intens; (5) kebutuhan betahan hidup; (6) hal-hal yang memiliki keutamaan pribadi; (7) hal yang diulag-ulang; (8) hal yang pertama dan terakhir (DePorter, 1999:. 214-216). Semua aktititas dan kualitas tersebut dilakukan dalam suasana menyenangkan sesuai prinsip edutainment.

\section{6) Berfikir Kreatif dan Logis}

Seorang yang kreatif selalu mempunyai rasa ingin tahu, ingin mencoba-coba, suka bermainmain, serta intuitif. Ketrampilan ini akan mendorong pikiran logis bekerja lebih baik.

\section{c. Kemampuan Berkomunikasi yang Menyenangkan}

Upaya membangun komunikasi yang menyenangkan dalam quantum learning teridentifikasi dalam pencermaan atas modalitas belajar, cara kerja otak dan membangun lingkungan belajar kondusif.

1) Modalitas dan Gaya Belajar

Gaya belajar Anda adalah kunci untuk mengembangkan kinerja dalam bekerja, belajar, dan situasi antar pribadi.Siswa yang akarab dengan gaya belajarnya sendiri akan mampu mengambil langkahlangkah penting untuk membantunya belajar lebih efektif. Setidaknya dikenal 3 modalitas belajar, antara lain: visual, auditorial, dan kinestetik.

\section{2) Memahami Cara Kerja Otak}

Pemahaman yang benar
tentang kerja otak akan
memudahkan interaksi dan
komunikasi yang menyenangkan
dalam lingkungan.

a) Teori otak triune (tiga otak dalam satu kepala).

Kita sebenarnya memiliki tiga otak. Setiap otak dikembangkan oleh otak yang lainnya. Didasar tengkorak terdapat otak primitif (otak reptil) yang membuat kita bernafas dan jantung berdetak. Bagian kedua adalah otak tengah atau system limbic (otak mamalia) yang mengendalikan hormone, emosi, system kekebalan dan merupakan bagian repenting dalam ingatan jangka panjang. Bagian ketiga adalah neo korteks atau otak berfikir, yang berisi 12-15 juta neuron dan cabang-cabangnya yang disebut dendrite (Rose, 2002: 18).

b) Teori otak kanan-otak kiri

Pada tahun 1950-an dan 1960an Roger Sperry menerima haiah nobel untuk karya penelitiannya tentang fenomena otak kanan dan otak kiri (Buzan, 2003: 19). Penelitian tersebut menunjukkan masing-masing elahan otak memiliki dan mengembangkan kemampuan di bidang yang berbeda. Otak kiri ersifat logis, sekuensial, 
linear, dan rasional.

Sementara otak kanan bersifat acak, intuitif, emosional, dan holistic (DePorter, 1999:.36-38)

Teori Sperry ini turut mendasari perubahan dan pengembangan quantum learning dan edutainment.

\section{3) Mengorkestra Lingkungan} yang Kondusif dan Optimal

Lingkungan sangat berpengaruh terhadap kualitas interaksi dan komunikasi. Mengutip pendapat Dhoroty (1991), DePorter mengatakan, segala sesuatu dalam lingkungan kelas kita menyampaikan pesan yang memacu atau menghambat belajar (DePorter, 2000: 66).

Lingkungan

yang

dibangun dalam konsep pebelajaran quantum learning meliputi lingkungan fisik maupun mental. Beberapa unsur lingkungan yang perlu dicermati untuk diorkestrasikan antara lain: (1) jenis dan penataan perabot; pencahayaan; (3) musik; (4) visual; (5) temperatur; (6) tanaman; (7) kenyamanan; (8) suasana hati.

Penataan lingkungan
optimal dalam quantum learning tersebut tentu sangat relevan dengan 4 karakteriktik edutainment dalam pembelajaran.

\section{PENUTUP}

Quantum Learning adalah metode pembelajaran yang sarat dengan konsep edutainment. Mencermati unsur-unsur edutainment dalam quantum learning seolah menyaksikan dua sosok pribadi kembar, yang memiliki banyak kemiripan. Analisis dalam makalah ini menujukkan begitu banyak kedekatan konsep antara keduanya yang terangkum dalam beberapa kesimpulan sebagai berikut:

1. Quantum learning dan edutainment sama-sama menekankan pentingnya suasana menyenangkan dan memudahkan.

2. Sama-sama bermula dari dunia non pendidikan. Quantum learning berawal dari dunia bisnis (Burklyn School), sedangkan edutainment berawal dari dunia hiburan (Walt Disney Company).

3. Keduanya memberi perhatian utama pada proses belajar yang menggairahkan, yang melibatkan fisikinderawi, emosi, dan keyakinan-sugetif.

4. Quantum learning menumbuhkan rasa percaya diri siswa, demikian pula pembelajaran edutainment memfasilitasi kesenangan dan kemudahan yang mendorong keyakinan dan rasa percaya diri siswa.

5. Quantum learning membangun ketrampilan belajar siswa melalui berbagai penemuan mutakhir, dan edutainment terus-meneus melakukan upaya baru dan kreatif dalam memfasilitasi proses pembelajaran optimal.

6. Quantum learning membangun komunikasi efektif melalui modalitas belajar, cara kerja otak,dan membangun lingkungan optimal, demikian pula edutainment berusaha menghadirkan komunikasi belajar tak berjarak dan lebih humanis. 


\section{DAFTAR PUSTAKA}

Agnes, Lindsey, The True Magic of NLP, Yogyakarta: Garailmu, 2010

Bobbi DePorter, Quantum Learning: Membiasakan Belajar Nyaman dan Menyenangkan, Bandung: Mizan Learning Center, 1999

Bobby DePorter, Quantum Teaching; Mempraktekkan Quantum Learning di Ruang-Ruang Kelas, Bandung: Kaifa,2000

Coilin Rose, Kuasai Lebih Cepat, terj. Femmy Syahrani, Bandung: Kaifa, 2002

Hamruni, Edutainment dalam Pendidikan Islam dan Teori-Teori Pembelajaran Quantum (Yogyakarta: Fakultas Tarbiyah UIN Sunan Kalijaga, 2009).hlm 50

Hernowo, Menjadi Guru yang Mau dan Mampu Mengajar Secara Menyenangkan, Bandung: MLC, 2004

Program Pascasarjana UIN Sunan Kalijaga Yogyakarta, Pedoman Penulisan Tesis, Yogyakarta, 2008.

Slamet Suyanto, Dasar-dasar Pendidikan Anak Usia Dini, Yogyakarta: Hikayat Publishing, 2005.

Tony Buzan, Head Strong: Memperkuat Hubungan Otak dan Tubuh untuk Mendapatkan Fisik dan Mental yang Fit (Jakarta: Gramedia Pustaka Utama, 2003

\section{Sumber Internet:}

Maziatul Churiah, "Quantum Learning", http://madziatul.blogspot.com/2009/0 3/quantum-learning.html

Sugiarto, "Akar-akar Landasan dalam Sistem Pembelajaran Quantum Learning”, http://sugiartoagribisnis.wordpress.co $\mathrm{m} / 2010 / 05 / 09 /$ akar-akar-landasandalam-sistem-pembelajaran-quantumlearning/

, "Quantum Learning" http://blog.unila.ac.id/momon/2009/0 9/07/bagaimana-strategi-pembelajaranquantum-teaching-dan-quantumlearning-dapat-dilaksanakan/ 